\title{
Czytając Elegie Rainera Marii Rilkego
}

Dla porządku odnotować należy pojawienie się wśród pozycji wydawniczych 2010 roku kilku polskich książek poświęconych Rainerowi Marii Rilkemu (1875-1926), poecie, którego talent poznał i docenił cały świat, a który w Polsce już w połowie lat dwudziestych ubiegłego wieku zaistniał w życiu literackim dzięki Witoldowi Hulewiczowi, niestrudzonemu tłumaczowi i popularyzatorowi jego dzieła, tłumaczonego od tego czasu po dziś dzień wciąż na nowo i wciąż na nowo odczytywanego. Mam na myśli publikacje: Marie von Thurn und Taxis-Hohenlohe, Wspomnienie o Rainerze Marii Rilkem w przekładzie Dariusza Guzika (wyd. Sic!, Warszawa 2010, ss. 160); Rainer Maria Rilke, Druga strona natury. Eseje, listy i pisma o sztuce, w przekładzie i z komentarzem Tomasza Ososińskiego (wyd. Sic!, Warszawa 2010, ss. 224) oraz będącą przedmiotem niniejszego wywodu książkę Rycerz i Śmierć. O Elegiach duinejskich Rainera Marii Rilkego (słowo/obraz terytoria, Gdańsk 2010, ss. 280) Katarzyny Kuczyńskiej-Koschany.

Rilke, urodzony i wzrastający w Pradze czeskiej w środowisku mniejszości niemieckiej, posługiwał się głównie językiem niemieckim, w którym to języku napisał swoje najwybitniejsze utwory. Mając łatwość uczenia się języków obcych, przyswoił sobie kilka z nich na tyle dobrze, by czytać interesujących go autorów w oryginale (na przykład Jensa P. Jacobsena czy Maurice'a Maeterlincka), zająć się m.in. tłumaczeniami Antoniego Czechowa (Wujaszek Wania, Mewa), tłumaczyć kongenialnie Slowo o polku Igoriewa, anonimowy francuski sermon Mitość Magdaleny, Listy portugalskie, sonety Louise Labé, sonety Elizabeth Barrett-Browning, Centaura Maurice'a de Guérina, Powrót syna marnotrawnego André Gide'a, poezje Paula Valéry'ego. Nadto Rilke prowadził, słusznie zaliczaną - tak jak przekłady - do jego oevre, korespondencję po niemiecku i w językach obcych oraz 
uprawiał własną twórczość w języku rosyjskim, a nade wszystko francuskim (francuskojęzycznym utworom Rilkego poświęcono jeden z pięciu tomów wydania krytycznego jego dzieł, przekłady natomiast mają zapełnić przygotowywany kolejny tom). Rilke spędził dzieciństwo i młodość w Czechach, obierając później na miejsce zamieszkania Niemcy i Francję (mieszkał w tym kraju kilkanaście lat), odbywał długie podróże po Europie oraz Afryce, a w ostatnich latach życia osiadł na stałe w Szwajcarii. Nie dziwi, że przy otwartości Rilkego na świat, jego języki i kultury, świat otworzył się na Rilkego. Polska kultura stała mu się bliska zwłaszcza dzięki serdecznemu związkowi z Baladine Klossowską, matką Baltusza, który - jak wiemy - szczycił się polskim pochodzeniem swej rodziny. Osobisty kontakt Rilkego z Witoldem Hulewiczem w 1924 roku zaowocował wymianą ich listów. Z korespondencji tej korzysta skwapliwie grono badaczy twórczości Rilkego, gdyż polski tłumacz ośmielił się przesłać poecie swego rodzaju formularz z prośbą o wyjaśnienie niejasnych dla niego kwestii, związanych z przekładem, takich jak np. znaczenie figury anioła w Elegiach. Rilke, niemający zwyczaju opatrywania swych utworów odautorskim komentarzem, wypełnił formularz. (Listy Rilkego do Witolda Hulewicza adresat ogłosił swego czasu w prasie polskiej. Zamieścił je także Tomasz Ososiński wśród przekładów w wymienionej wyżej książce: Rainer Maria Rilke, Druga strona natury. Eseje, listy i pisma o sztuce). Stąd łatwo dzisiaj powiedzieć, że anioł Elegii duinejskich nie jest tożsamy $\mathrm{z}$ aniołem religii chrześcijańskiej. Korzysta $\mathrm{z}$ tej wiedzy - jak możemy się przekonać - także Katarzyna Kuczyńska-Koschany, autorka omawianej publikacji.

Katarzyna Kuczyńska-Koschany wydała uprzednio w serii humanistycznej „Monografie FNP” książkę pt. Rilke poetów polskich (Wrocław 2004, ss. 440), jest też autorką paru innych tekstów poświęconych Rilkemu. W swej najnowszej książce umieściła, zgodnie z zawartą w niej informacją, ogłaszane wcześniej szkice, „teraz w wersji poprawionej i uzupełnionej” (s. 7). Mamy przed sobą publikację pożądaną, choćby z tego względu, że to pierwsza w naszym kraju obszerna i wnikliwa praca skupiona na jednym cyklu poetyckim Rilkego złożonym $\mathrm{z}$ dziesięciu elegii, uznanym przez niego samego za szczytowe osiągnięcie twórcze. Takie przedsięwzięcie wymaga nie lada wysiłku. Do lektury zachęca obietnica autorki zajęcia się w interpretacji Elegii zaniedbywaną dotychczas w naszej krytyce literackiej analizą porównawczą istniejących przekładów i uwzględnienia niemieckiej literatury przedmiotu. Zabieramy się zatem do czytania jej opracowania z dużymi oczekiwaniami. Czytelnik, który bierze nowo 
wydaną książkę do ręki, pierwsze informacje czerpie ze skrzydełka. I tu niespodzianka. Z pewnym niedowierzaniem wczytuję się w pierwsze zdanie o tomie 11 serii, zawierającym Rycerza i Śmierć: „Pierwsza polska monografia Elegii duinejskich - najdojrzalszego dzieła Rainera Marii Rilkego, pisanego w zmaganiu z śmiertelną chorobą". Otóż tylko początkowa część tego zdania jest prawdziwa, reszta, informująca o zmaganiu ze śmiertelną chorobą, niestety nie. Rilke, spisując Elegie duinejskie, nie podejrzewał choroby, tym bardziej śmiertelnej. Księżna Marie von Thurn und Taxis-Hohenlohe, spiesząca na wezwanie poety do położonego w szwajcarskim kantonie Wallis Muzot, by tam, w starym zamku oddanym mu na własność przez przyjaciół, wysłuchać ukończonych przez niego dopiero co cykli elegii i sonetów, znajduje go w znakomitej formie: „Ujrzałam przed sobą człowieka odmienionego, promieniejącego szczęściem” (M. von Thurn und Taxis-Hohenlohe, Wspomnienie o Rainerze Marii Rilkem, przekład Dariusza Guzika, s. 128 i n.). Zdarzyło się to w czerwcu 1922 roku, a dopiero z początkiem roku 1923 dały o sobie znać groźne symptomy nieuleczalnej choroby poety.

Pierwszy rozdział książki opatrzyła autorka tytułem „Dziesięć dobrych wierszy”, odnoszącym się do przytoczonej przez nią na wstępie tego rozdziału wypowiedzi z Maltego: „Ach, te poezje to takie nic, kiedy się je pisze za młodu. Powinno się z tym czekać i gromadzić sens i słodycz przez całe jedno życie, i to długie, o ile możności, a potem na samym końcu, może potem mogłoby się napisać dziesięć dobrych wierszy" (s. 7). Kuczyńską-Koschany ucieszyło zapewne, że Rilkowskich elegii, które są niewątpliwie dobrymi wierszami, jest akurat dziesięć - tyle ile trzeba, by sprostać sentencji. Niestety, nie zajrzała do oryginału Pamiętników Malte Lauridsa Brigge i dlatego dała się złapać w translatorską pułapkę. W oryginale niemieckim Rilke formułuje rygorystycznie „zehn Zeilen”, a to znaczy „dziesięć linijek”, „dziesięć wersów”, nie: wierszy-utworów literackich. Kuczyńska-Koschany zbytnio zawierzyła Hulewiczowi, który przetłumaczył „Zeilen” przez „wiersze”, myśląc być może o wersach, a może źle rozumiejąc Rilkego. Szkoda, że pomysł autorki Rycerza i Śmierci $\mathrm{z}$ dziesięcioma dobrymi wierszami okazał się chybiony.

W kolejnym rozdziale zatytułowanym „Uwertura” autorka, tłumacząc znaczenie tytułu Elegie duinejskie, zauważa, że „nie wszystkie utwory tego cyklu powstały w Duino, dalmatyńskiej miejscowości nad Adriatykiem" (s. 15). W tym momencie jednak daremnie czekamy na dopowiedzenie, które z elegii zrodzily się tutaj, a które gdzie indziej. Poza tym autorka zatrzymuje naszą uwagę jedynie przy pierwszej elegii, od której jakoby wyszedł 
impuls nazwania całego cyklu Elegiami duinejskimi. Nieco inaczej rzecz będzie wyglądać, jeśli uwzględnimy to, co poeta odnośnie tytułu napisał w liście do Georga Reinharda z 19 grudnia 1923 roku: „Elegie - to dla objaśnienia tytułu - nazywają się »duinejskimi «, na pamiątkę (thurn-i taxisowego) zamku Duino (nad Adriatykiem), gdzie, w samotni niewymownej zimy 1912 roku, napisane zostały pierwsze dwa (i niejeden fragment planowanych kolejnych utworów). Okoliczność, że stary duinejski zamek pod koniec wojny został całkowicie zrujnowany, sprawiła, iż zdecydowałem się nazwę zniszczonego gmachu związać na zawsze z owym poetyckim kręgiem: pomimo że ich obrzeże nie zostało tam ukończone, to centrum, które zachowałem, tam mi się objawiło, wielki promień (który tutaj [w Muzot] dopiero został całkowicie domknięty) tam wszedł w moje posiadanie" (przekład - B.S.).

Poruszając temat sporu toczonego pomiędzy zwolennikami Elegii duinejskich i Sonetów do Orfeusza o prymat jednego cyklu nad drugim, autorka zauważa niepewnie, że sam Rilke „raczej nie wartościował, nie tworzył hierarchii, lecz wskazywał na rozmiar gatunkowy pojedynczych utworów i na tonację wypowiedzi poetyckiej” (s. 9). Tymczasem znane jest przecież wyznanie poety, iż zrazu przedkładał elegie nad sonety i dopiero reakcja księżny Thurn und Taxis-Hohenlohe na obydwa cykle, które jej jako pierwszej odczytał, pozwoliła mu dowartościować sonety i stawiać je na równi z elegiami. Zaświadcza to fragment ich korespondencji: „Sonety zaś, którem traktował $\mathrm{z}$ większą pobłażliwością aniżeli ich starsze, bardziej dostojne rodzeństwo, elegie - dopiero Pani, Księżno, poprzez ów wspaniały sposób, w jaki się im przysłuchiwałaś, ofiarowałaś mi ich pełne, właściwe znaczenie. Proszę mi wierzyć: dopiero Pani aprobata dopełniła dzieła, czyniąc je bogatym i szczęśliwie ukończonym. Przyjmij Pani słowa podzięki, nigdy jeszcze nasze spotkanie nie wydobyło dojrzalszych owoców [...]" (M. von Thurn und Taxis-Hohenlohe, Wspomnienie..., s. 131).

Stwierdzenia autorki książki: „Rilke pracował długo i żmudnie nad Elegiami” (s. 11) bądź też „wieloletnia praca myśli, która poprzedziła kolejność tekstów zaproponowaną czytelnikowi, uczyniła z cyklu przypadkowego - cykl zwarty, z fragmentów pisanych nieregularnie - całość, z kaprysów Muzy - arcydzieło" (s. 12) zawieraja wyraźną sugestię, że Elegie powstawały fazami, stawiając opór poecie. Jestem skłonna przyjąć, że uporządkowanie stworzonego cyklu wymagało pewnego namysłu, natomiast pojawianie się zarówno pierwszych elegii, jak i ostatnich, dopełniających cykl, było dla poety nagłe i niespodziewane. Katarzyna Kuczyńska-Koschany zresztą sama przytacza wspomnienie księżny Thurn und Taxis-Hohenlohe 
o okolicznościach powstania pierwszej elegii w ciągu jednego dnia, czyni to na s. 16-17 swej książki. Rilke, jak wspomina księżna, „nie spodziewał się tego, co miało nastąpić” - z tym że księżnej nie dowierza, dopatrując się w jej słowach zaczynu legendy. Ze wspomnień księżny można przytoczyć mieszczący się $\mathrm{w}$ omawianym kontekście inny jeszcze zapisek, w którym została utrwalona rozmowa Rainera Marii Rilkego z francuską poetką Anną de Noailles o akcie twórczym: „W sposób wielce osobliwy Mme de Noilles żaliła się przed poetą, jakich ogromnych trudności może czasem nastręczać sama forma lirycznego wersu, jak wielkiego wysiłku wymaga nierzadko owo zmaganie. Rilke spojrzał wówczas na hrabinę swymi dużymi oczami, w których kryło się zdumienie. - Jakże to, nie sądzi pan, iż to niekiedy okropnie żmudne? - pytała raz za razem. - Ależ skąd, bynajmniej... - Wydawało się, że poeta nie potrafi tego pojać. Mniemam, iż Mme de Noailles nie potraktowała jego odpowiedzi z należytą powagą. Dopiero gdy bliżej poznałam Rilkego, zrozumiałam, jak wiele prawdy kryło się w tym zdaniu. Poeta bowiem nie napisał nigdy bodaj pojedynczej linijki wiersza, nie czując $w$ sobie inspiracji i wewnętrznego przymusu. Oddawał się im bez reszty, nie uświadamiając sobie zazwyczaj, jakim sposobem niewielki notes, który zawsze miał przy sobie, zapełniał się zapiskami. Rilke pokazywał mi go wielekroć; za każdym razem ogarniało mnie zdumienie, kiedy spoglądałam na czyste, wyraźne pismo, bez śladu jakiejkolwiek korektury" (M. von Thurn und Taxis-Hohenlohe, Wspomnienie..., s. 16). Powyższa rozmowa odbyła się w Paryżu w 1909 roku podczas pierwszego spotkania Rilkego i księżny. W roku 1922, gdy powstawało sześć ostatnich elegii i aż pięćdziesiąt siedem sonetów, Rilke spisywał rodzące się wiersze jak w transie. „Wszystko to”, wspomina księżna, „stworzył w przeciagu kilku zaledwie dni - elegie bodaj w trzy. Poeta wyznał mi, iż myśl o pisaniu zawładnęła nim jak gorączka, nie mógł zasnąć ani jeść, ledwie nadążał przelewać na papier słowa cisnące się pod pióro. Kiedy kilkakroć wychodził na dwór, pragnąc zaczerpnąc świeżego powietrza, zaraz musiał na powrót sięgać po notes i pisać dalej - gorączkowo, nieprzerwanie...” (M. von Thurn und Taxis-Hohenlohe, Wspomnienie..., s. 130). Nie jestem skłonna uznawać, że działo się inaczej.

O Pierweszej Elegii Katarzyna Kuczyńska-Koschany powiada: „najistotniejsze jest to, iż wyznacza ona główne tematy i stylistyczno-rytmiczny charakter całego cyklu" (s. 20). I znowu nie mówi, jakie to główne tematy wyznacza owa elegia, przechodząc od razu do bliższego określenia stylistyczno-rytmicznego charakteru Rilkowskich wierszy.

Z pozytywów rozważań Kuczyńskiej-Koschany na temat elegii wypada odnotować wyrażoną przez nią w oparciu o dość 
powszechne stanowisko badaczy opinię, że Rilke w znaczący sposób odmienił jej „oblicze”. Rilke już jako autor Noreych Wierszy, których początek datujemy od czasu powstania słynnej Pantery, tj. od roku 1903, wyznaczał nowe kierunki poezji, wypracowując nieznany dotąd typ wiersza zwany „Dinggedicht”, w którym liryczne „ja” nie manifestowało swojej obecności, ustępując miejsca „rzeczy”, która niczym rzeźba kamienna zawierała się w sobie, „tylko sobą zajęta” - mówiąc słowami ich twórcy. Okres pisania tak pojmowanej poezji skończył się dla poety około roku 1908. W tym samym czasie, w którym Rilke koncypował swoje „Dinggedichte”, zebrane następnie w dwuczłonowym zbiorze Nowe Wiersze i Nowych wierszy czesśc druga, pisał „Zwartą prozą” Pamiętniki Maltego Lauridsa Brigge. I była to niezwykle frapująca propozycja nowoczesnej powieści, z poszarpaną akcją, prowadzoną bez zachowania chronologicznego porządku, dziejącą się na przemian w czasie minionym i tu i teraz, z nadwrażliwym bohaterem, bezradnym wobec współczesności, w której nie znajdował Boga, przerażonym wielkomiejskim życiem, uciekającym we wspomnienia utraconego dzieciństwa lub do świata książek i usiłującym przezwyciężyć swe egzystencjalne lęki pisaniem.

Ukończenie Maltego, a właściwie pozostawienie tej książki we fragmentarycznej postaci w roku 1909 zakończyło ów nader ciekawy i płodny Rilkowski eksperyment z prozą.

W przypadku Rilkego nie byłoby możliwe powracanie do tego, co z form poetyckich już wypracowane. Musiał on znaleźć taki gatunek poezji, który pozwoliłby mu wyrazić niemal niewysłowione problemy człowieka współczesnego. Takim wymaganiom zdawała się odpowiadać elegia, ale elegia unowocześniona, pojemniejsza, pozwalająca objąć swym zasięgiem nieogarniane przez nią do tej pory treści. Katarzyna Kuczyńska-Koschany, próbując ustalić, w czym elegia Rilkego odbiega od swego wzorca gatunkowego, odwołuje się do konstatacji Anny Legeżyńskiej, że: „Od Elegii duinejskich R.M.Rilkego [...] wzorzec elegijności na stałe poszerza się o refleksję filozoficzną i metafizyczną" (s. 12). Dwie pierwsze elegie Rilkego powstały, jak powiedzieliśmy, na początku roku 1912. Kolejne dwie - niedługo później, reszta zaś już w latach dwudziestych. Na okres, który dzieli pierwsze i ostatnie elegie, przypadają lata poprzedzające wybuch I wojny światowej, lata jej trwania i lata następujące tuż po niej. Wypracowywana przez poetę koncepcja elegijnego cyklu mieściła w sobie - pomimo wszystko - afirmację życia. Utwory te miały sławić to, co żyje i co umiera, jako że śmierć należy do bytu. Miały wskazywać na jednię istnienia. I miały głosić wielkość sztuki 
i poezji, ocalającej wszelkie przemijające formy istnienia przez przemienianie ich i czynienie ich niewidzialnymi i niezniszczalnymi, trwającymi wiecznie. Przeżyty koszmar wojny nie stwarzał warunków do głoszenia takich treści. Musiał przeminąć, by stało się to możliwe. Wojna zaskoczyła Rilkego - jak wiemy poza granicami Francji, do której już nie mógł powrócić. Przebywał w Monachium pod stałym adresem, oczekując powołania do wojska. Wyreklamowany m.in. przez księcia Aleksandra, małżonka Marii von Thurn und Taxis-Hohenlohe, od ciężkiej służby wojskowej, został zatrudniony $\mathrm{w}$ archiwum wojennym w Wiedniu i wkrótce potem zwolniony do cywila. Wyposażenie jego paryskiego mieszkania sprzedano pod jego nieobecność na licytacji. Utracił bezpowrotnie cały dobytek, pozostawione tam manuskrypty, książki i pamiątki. Musiało upłynąć kilka lat, nim stał się panem na zamku w Muzot, gdzie odzyskał spokój i gdzie poczuł przypływ potencji artystycznych.

Katarzyna Kuczyńska-Koschany powtarza za Hansem-Georgem Gadamerem, „iz Elegie duinejskie jak wszystkie elegie są skargą [...]. Rdzeń tematyczny owej skargi został najlapidarniej ujęty w bliźniaczych Sonetach do Orfeusza (I, 19), w słowach » nie nauczono się miłości « (»nicht ist die Liebe gelernt «), a nieco szerzej w Anty-strofach [...]”, w których „przedmiotem skargi jest nieosiągalność dla kochanków prawdziwego szczęścia, albo raczej niezdolność kochanków, zwłaszcza kochającego mężczyzny, do takiej miłości, która dałaby prawdziwe spełnienie" (s. 13 n.). Jest to wszystko prawdą, ale kwestia kochających należy do całej gamy tematów, z którymi mamy do czynienia w Elegiach i Sonetach także. Była już wcześniej mowa o tym, że autorka omawianej książki tych tematów nie określiła, dlatego wydobywa tutaj jeden z nich, by mówić o słabości ludzkiego uczucia, które nie potrafi sprostać doświadczeniom takim jak miłość i śmierć, zwłaszcza śmierć przedwczesna.

Odkrywszy w Anty-strofach, w których doczytuje się „swego rodzaju streszczenia Elegii" - co jest dla mnie konstatacją tyle dowolną, co niezrozumiałą - charakterystykę kobiecości, Kuczyńska-Koschany uznaje za komplementarną wobec niej „tę dotyczącą chłopięcości (męskości)”, a wyrażoną w tetrastychu z 9 lutego 1922 roku:

Wir, in den ringenden Nächten, wir fallen von Nähe zu Nähe; und wo die Liebende taut, sind wir ein stürzender Stein. 
[My, w naszych nocnych zmaganiach, między jednym a drugim zbliżeniem, tam gdzie kochanka jak rosa, padamy ciężko jak głaz.]

(Przekład A. Pomorskiego)

Nie wiem, doprawdy, jakiej charakterystyki kobiecości można się doczytać z przekładu Pomorskiego, który popełnił tu dwa błędy naraz. Po pierwsze tłumacząc „die Liebende” przez „kochanka”, bez uwzględnienia tej różnicy, że „die Liebende" (kochająca) to dla Rilkego kobieta, która darzy ukochanego uczuciem czystym, nie pożądając go, podczas gdy kochanka (die Geliebte) pragnie zaspokojenia miłosnej tęsknoty. A po wtóre, myląc niemiecki czasownik „tauen” (tajać, topnieć) z rzeczownikiem „der Tau” (rosa) i tworząc w związku z tym porównanie „kochanka jak rosa”, które skutecznie niweluje występujące w wierszu Rilkego przeciwstawienie kobiety o czułym sercu, topniejącym w ogniu miłości i kochanka, mężczyzny, z sercem twardym jak głaz.

Spróbujmy teraz skupić uwagę na interpretacji Pierweszej Elegii Rilkego, powstałej 21 stycznia 1912 roku na zamku w Duino.

Zacznijmy od oryginalnego brzmienia początku tego wiersza: „Wer, wenn ich schriee, hörte mich denn aus der Engel Ordnungen”. W cytacie przytoczonym przez Katarzynę Kuczyńską-Koschany zabrakło wzmacniającego „denn”, a przecież poprzestaje ona na owym incipicie, więc powinna była cytować dokładnie, tym bardziej, że zestawiając polskie przekłady tej frazy, zastanawia się akurat nad zachowaniem jej rytmu w kilku polskich wersjach językowych. W dodatku frazę ową bez „denn” autorka książki powtarza w dalszym ciągu swojego wywodu.

Nie jest to, niestety, jedyne potknięcie autorki przy odczytywaniu niemieckiego tekstu Pierweszej Elegii, przechodząc bowiem $\mathrm{w}$ pewnym miejscu interpretacji tego wiersza do charakteru i roli występującego w niej anioła, odwołuje się do słów Jacoba Steinera, któremu zresztą zawdzięcza niejedno spostrzeżenie: „Podając swoją definicję Anioła i zderzając ją z definicją człowieka jako istoty, określił Rilke - tu całkowicie zgadzam się ze Steinerem zasadniczy temat Elegii: Przemianę. Przemiana Widzialnego w Niewidzialne, powiada monografista cyklu duinejskiego, »dokonuje się tam, gdzie nie ma niczego więcej niż Wnętrze « (»ist dort vollzogen, wo nichts mehr ist als das Innere «). Pokonać obcość anielskiego bytu znaczy uwewnętrznić ją; mówi o tym fraza Pierwszej Elegii: »es nähme / einer mich plötzlich ans Herz «. Być nagle złapanym za serce (ów najwewnętrzniejszy 
z organów) przez Anioła, nawet pięknego, jak każe nam wierzyć tradycja śródziemnomorska, oto inicjał przerażenia" (s. 21).

I tu dochodzi do nieporozumienia, bo „es nähme einer mich plötzlich ans Herz” nie znaczy „być złapanym za serce przez Anioła". Tu chodzi o serce anioła, nie o moje. Jastrun tłumaczy dokładnie: „A gdyby nawet któryś z aniołów / przycisnął mnie nagle do serca: musiałbym umrzeć / od jego silniejszej istoty" (R.M. Rilke, Poezje, wybrał, przełożył i posłowiem opatrzył M. Jastrun, Wydawnictwo Literackie, Kraków 1993, s. 185).

Tym bardziej niezrozumiałe staje się dla mnie to złe odczytanie Rilkowskiego sformułowania przez autorkę, że mówiła ona uprzednio - zdecydowanie - o dystansie, „chłodzie” anioła względem człowieka, którego wołania anioł z tego właśnie względu usłyszeć nie może. Dlaczegóż by zatem ten zdystansowany do człowieka anioł miał dotykać człowieczego serca? Rilke zakłada rzecz nieprawdopodobną, że oto człowiek pożądający bliskości anioła zostaje przez niego przygarnięty. A niewiarygodne to dlatego, że uścisk anioła byłby dla człowieka śmiertelny.

Także w innym jeszcze miejscu interpretacji Pierweszej Elegii wyczuwamy, że autorka nie do końca rozumie oryginał. Oto tłumaczy bowiem słowa Eduarda Mörikego dotyczące anioła "selig in ihm selbst" jako „błogosławiony w sobie samym” (s. 21). "Selig” w tym wypadku może - moim zdaniem - znaczyć tyle, co „sam sobie wystarcza”, w sobie samym znajduje błogość i szczęście.

Kuczyńska-Koschany zwraca uwagę na komentarz Jacoba Steinera do listu Rilkego do barona Uexküll z 19 sierpnia (nie lipca - jak mylnie przetłumaczono „August”) 1909 roku, w którym mowa o Nowych wierszach Rilkego, zawierający - jego zdaniem - już „całe wyobrażenie anioła, który jest tą samą stroną, co Piękno, więcej: co sztuka, jednocześnie na jej krańcu” (s. 22). Przekładu dokonała autorka, ale niezbyt udatnie, bo trudno zrozumieć, o co tutaj chodzi. Dlaczego piękno ma się znajdować na krańcu strony? I jak rozumieć, że jedno i drugie jest tą samą stroną? Jestże anioł stroną, tak samo jak piękno, czy tylko jej krańcem? Otóż Steiner nic nie wspomina o stronie, używa zupełnie innego terminu, mianowicie „die Richtung”, a to znaczy „kierunek”. Wypatrując anioła, trzeba kierować spojrzenie tam, gdzie piękno, ku sztuce, na której krańcu będzie się znajdował (stanowiąc dzieło doskonałe, absolutnie piękne).

Dalej Kuczyńska-Koschany mylnie przyjmuje, że anioł w ujęciu Rilkego jest „,bytem z tamtej strony”, podczas gdy Rilke w Pierwszej Elegii właśnie mówi o aniołach, że - jak wieść niesie - często nie wiedzą, w jakie wkraczają obszary, żywych czy 
umarłych: „Engel (sagt man) wüßten oft nicht, ob sie unter / Lebenden gehn oder Toten. Die ewige Strömung / reißt durch beide Bereiche alle Alter / immer mit sich und übertönt sie in beiden". A zaczyna poeta ten fragment od wypomnienia żyjącym, że popełniają błąd, odróżniając właśnie zbyt mocno - w domyśle: gdzie region życia, gdzie śmierci. Elegie głoszą istnienie jedni, niwelują granice tego, co doświadczalne zmysłowo, i tego, co niewidzialne.

Kuczyńska-Koschany niepotrzebnie udziwnia zarówno wypowiedzi Steinera, jak i Rilkego. Steiner mówi jakoby o krzyku człowieka „z najgłębszego zwątpienia”, podczas gdy Steiner pisze najwyraźniej o „krzyku najgłębszej rozpaczy” („aus tiefster Verzweiflung”). „Die Verzweiflung” znaczy „rozpacz”, „der Zweifel” natomiast - „Zwątpienie”. Ten krzyk człowieka oznacza - zdaniem autorki ,jednoczesną skargę i wołanie o pomoc”. „Lecz kogo możemy oswoić?” - pyta rzekomo w tym kontekście Rilke. Oryginał jednak nie każe nam myśleć o oswajaniu nikogo. Pytanie jest sformułowane inaczej: „Ach, wen vermögen / wir denn zu brauchen?”. Dokładnie przełożył to Jastrun: „Ach, któż mógłby nam być / użyteczny?” (s. 185). Zrozpaczony człowiek szuka wszak pomocy, lecz nie wie, do kogo się zwrócić, by znaleźć oparcie. Myślę, że inspiracją była tutaj dla Rilkego „Księga Hioba” ze Starego Testamentu: „Wołaj! Czy ktoś ci odpowie? I Do kogo ze świętych się zwrócisz?” (3, 18-5,1; Pismo Święte Starego $i$ Nowego Testamentu. W przekładzie zjęzyków oryginalnych, opracował zespół biblistów polskich z inicjatywy Benedyktynów Tynieckich, wyd. czwarte, Wydawnictwo Pallatinum, PoznańWarszawa 1989).

I jeszcze jeden przykład dotyczący tłumaczenia, tym razem Adama Pomorskiego, które znajduje uznanie autorki, a które mnie zupełnie nie zadowala. Występuje w tym oto akapicie: „Kolejna cząstka Pierwszej Elegii stoi pod znakiem nocy, rozumianej za Novalisem jako » pora duszy « (»die Tageszeit der Seele«) [...]. Jeszcze noc nam zostaje, gdy »cały wszechświat wiatrem / wyżera nam twarz (jak pięknie przełożył to Pomorski) [...]” (s. 23). A tak napisane jest w oryginale: „O und die Nacht, die Nacht, wenn der Wind voller Weltraum / uns am Angesicht zehrt" - czyli uaktywniony jest wiatr, który dokonuje zniszczeń na naszej twarzy; nie wszechświat, lecz wiatr przychodzący z wszechświata, wypełniony nim. Jastrun oddał tę myśl następująco: „gdy wicher pełen przestworów niszczy nam twarz” (R.M. Rilke. Poezje. Gedichte, s. 185).

Bardzo ważnym terminem w myśleniu Rilkego o człowieku, a zwłaszcza o człowieku twórczym, jest „Weltinnenraum”. Jest 
to świat przywołany z pamięci, zgodnie ze stwierdzeniem poety: „die ganze Welt ist als erinnerte erst Weltinnenraum” („cały świat jest jako przypomniany dopiero Weltinnenraum"). Kuczyńska-Koschany pogubiła się trochę $\mathrm{w}$ thumaczeniu, bo przełożyła „erinnerte” jako „przypomniane”, nie zważając na to, że przymiotnik ten odnosi się do „die Welt”. W rezultacie powstało opaczne thumaczenie: „Cały świat jako przypomniane to najpierw Weltinnenraum".

Najtrafniej nieprzekładalne to słowo - zdaniem autorki określił Grzegorz Zygadło, „pojmując neologizm Rilkego jako »wewnętrzną przestrzeń, wyzwoloną spod dyktatu czasu «. Stąd” - wnioskuje autorka - „odwołanie do ptaka w zamknięciu pierwszej części Pierweszej Elegii: »vielleicht daß die Vögel / die erweiterte Luft fühlen mit in nigerem Luft « [na końcu powinno być „Flug”, a nie „Luft”] (jak tłumaczy Napierski: »ptaki, być może, / rozszerzone powietrze odczują tkliwszym przelotem « $[. .]$.$" (s. 24).$

Niepokoi mnie to, że autorka ptaki te widzi w zamknięciu, w dalszej partii swego tekstu jeszcze tę myśl wzmacniając przez powtórzenie: „Dlatego ptak w Pierwszej Elegii i muszka w Ósmej Elegii, małe stworzenia zamknięte w bezpiecznej przestrzeni (godów, gniazda) [...]”" (s. 24). Otóż w Pierwszej Elegii ptaki znajdują się w locie, nie w gnieździe! A lot ich być może czulej odbiera "rozszerzoną przestrzeń świata”, bo one lecąc i odzywając się w górze, są w swoim żywiole i śpiewem ubogacają przestworza, inaczej niż my, bo ruch naszych otwierających się ku górze ramion niczego przestworzom nie doda. Lot i śpiew ptaków są czulsze od naszych zachowań i od naszego wołania. Autorka, próbując dociec znaczenia tej pięknej figury poetyckiej, jaką jest w poezji Rilkego lot ptaka, nie powinna, wychodząc od Pierwszej Elegii, poprzestawać na odwołaniu do Elegii Ósmej, skoro zajmuje się całym cyklem elegijnym Rilkego, bo figura ta występuje również w elegiach Czwartej, Siódmej i Dziesiatej. W każdej z nich poeta wskazuje na wyższość natury ptaka, a nawet muszki, nad naturą człowieczą, bo stworzenia te znają obszary dla człowieka niedostępne. Nie czują granicy między wnętrzem i tym, co zewnętrzne. W Czwartej Elegii powiedział poeta: „Wir sind nicht wie die Zugvögel verständig” - to znaczy, że nie pojmujemy tyle, co ptaki przelotne. Jesteśmy ułomniejsi. W Siódmej mowa o naszym i ptaka wołaniu, którym należałoby się dokładnie zająć. I warto by było też zwrócić uwagę na to, że czułość, przypisana w pierwszym utworze cyklu lotowi ptaka, w tym przynależy niebiosom. W Dziesiątej Elegii, zamykającej cykl, lot ptaka przekazuje coś szczególnego. Pojawiają się dwa obrazy. Pierwszy 
ukazuje ptaka, który zerwał się spłoszony do lotu „und zieht, flach ihnen fliegend durchs Aufschaun, / weithin das schriftliche Bild seines vereinsamten Schreis".

Drugi obraz musimy łączyć z przeżyciem poety w Egipcie, gdy nocą, którą spędzał w absolutnej ciszy samotnie pod figurą sfinksa w Gizie, zareagował na cichy przelot sowy, tuż przy twarzy sfinksa. I pierwszy, i drugi lot są osobliwe. Pierwszy odbywa się z krzykiem, drugi - równie wymowny - jest cichy. W jednym można się dopatrzyć wzlotu (ku życiu), w drugim zniżania (ku śmierci). (Figura lotu spłoszonego ptaka i przelotu sowy została doskonale skomentowana $\mathrm{w} \mathrm{V}$ tomie, na s. 698 wydania krytycznego dzieł Rilkego: Werke. Kommentierte Ausgabe in vier Bänden, hrsg. von Manfred Engel und Ulrich Fülleborn, Insel Verlag Frankfurt am Main und Leipzig 1996).

Drugiej Elegii, o której mowa w rozdziale „Gdzie są dni Tobiasza...", autorka - wbrew oczekiwaniu - nie omawia w powiązaniu z pierwszą, choć Rilke, powtarzając użytą w niej frazę „Jeder Engel ist schrecklich” („Każdy anioł przeraża” w tłumaczeniu Jastruna), przywołuje postać anioła, której to postaci w tamtym, otwierającym cykl utworze nadał pierwszorzędne znaczenie. Anioł - w ujęciu Rilkego - jest straszny, przeraża, bo jest bytem silniejszym od ludzkiego, takim, który nie zna granicy między tym, co widzialne, i tym, co niewidzialne. Człowiek nie byłby zdolny znieść jego widoku. Według starotestamentowej przypowieści biblijnej, do której w Elegii nawiązują słowa, „Gdzie są dni Tobiasza...”, Tobiasz, syn Tobita, na polecenie ojca udał się w drogę do nieznanego mu miejca, Raga w Medii, w towarzystwie archanioła Rafaela, który - występując w przebraniu - służył mu za przewodnika. Poeta przywołuje ten fragment przypowieści dla przeciwstawienia swojego strasznego anioła archaniołowi Rafaelowi, który przyjął zewnętrzny wygląd człowieka, by Tobiasz, nic nie wiedząc o jego właściwej naturze, obcował z nim bez bojaźni. Dla nas, ludzi, nieziemski widok anioła byłby zabójczy. Jego istota jest nieodgadniona. Archanioł Rafael pośredniczy między Bogiem i ludźmi. Przedkłada Bogu ich potrzeby i uprasza łaskę ich zaspokojenia. Rilkowski anioł natomiast skarg ludzkich nawet nie słyszy, a gdyby nawet usłyszał, nie mógłby ludziom służyć pomocą.

Rilke w Elegiach nie zmierza ku jednoznaczności. Stworzone przez niego anioły są straszne i piękne zarazem. To lustra: które swą piękność zniknioną / na nowo wchłaniają w swe własne oblicze" (przekład Jastruna, s. 191).

Katarzyna Kuczyńska-Koschany nie próbuje wytłumaczyć, jak Rilke buduje i dalej rozwija koncepcję anioła, prowadząc nas 
od elegii do elegii, tylko zbaczając z tej drogi, gdy zaprząta naszą uwagę wierszem Jastruna pt. Życiorys napisany ołówkiem, w którym mowa o Tobiaszu niosącym „dla ślepego ojca rybią żółć” (s. 34). Dotyczy to innego wątku starotestamentowej przypowieści o Tobiaszu, który - za radą anioła - rybią żółcią potarł przesłonięte bielmem oczy ojca, ratując go tym sposobem od ślepoty. Ów anioł, który ongiś wybawił człowieka od nieszczęścia, był niepodobny do anioła Rilkego, bo ten „szedł wśród żywych i zmarłych / obojętny na śmierć i cierpienie" (Rycerz $i$ Śmierć, s. 33). Teraz, w dobie okrutnych doświadczeń wojennych, „Żadne zaklęcie / nie wskrzesi ludzi i słów zabitych" (Rycerzi Śmierć, s. 33) - puentuje Jastrun.

Tak rzecz wygląda $\mathrm{z}$ perspektywy Jastruna. Rilke napisał Pierresząi i Drugą Elegię, jak pamiętamy, w roku 1912. Na dwa lata przed wybuchem pierwszej wojny światowej (do drugiej nie dożył), toteż nieupoważnione jest - moim zdaniem - twierdzenie autorki Rycerza i Śmierci, że Rilke zapowiadał katastrofę. Wszak wcześniej, w „Uwerturze”, Katarzyna Kuczyńska-Koschany orzekała z przekonaniem o Elegiach i Sonetach: „obydwa cykle łączy poetyka afirmatywna (Poetik des Rühmens), lecz w Sonetach jest ona bardziej jednoznaczna, w Elegiach zaś bardziej dramatyczna" (s. 10).

Nie wiem, czy trzeba było potem wprowadzać „długą dygresję poświęconą specyfice religijności Rilkego" (s. 34-36) po to, by jak tłumaczy autorka - „przygotować objaśnienie metamorfozy postaci biblijnych w inicjalnych strofach Drugiej Elegii", bo nie bardzo rozumiem, o jakich metamorfozach, o jakich postaciach biblijnych tu mowa. Poza aniołem z dni Tobiaszowych żadnej innej postaci biblijnej Rilke w tej Elegii nie przywołał. Archanioł Rafael należy do wyobrażeń chrześcijańskich, natomiast anioł Rilkego zdecydowanie nie, więc nie mówmy o metamorfozach, bo chodzi o dwie różne postacie $\mathrm{z}$ dwóch różnych kontekstów.

Jak już zaznaczyłam wyżej, autorka nie wyróżniła, niestety, występujących w Pierweszej Elegii ważnych dla całego cyklu tematów i motywów. Należy do nich anioł, wielkie miłujące czy przedwcześnie umarli. W Pierweszej Elegii rozbrzmiewa skarga na bezradność człowieka wobec doświadczeń życiowych. Zda się, że znikąd nie doświadczy wsparcia. Ani od aniołów, ani od ludzi i zwierząt. Być może jakąś pociechą będzie mu kontakt $\mathrm{z}$ naturą i z rzeczami w znanym otoczeniu. Poza obszarem codziennych doświadczeń w świecie, który jest wytłumaczalny, są obszary dostępne wyostrzonym zmysłom i spotęgowanemu uczuciu. Zdarzają się noce, które przynoszą jakiś wiew wszechświata, „leicht ersehnte, sanft enttäuschende”, noce upragnione, lecz 
nieco rozczarowujące. Człowiek, nawet obdarzony wielką wrażliwością, zdolny do miłości, gdy kocha wzajemnie, zbyt się utożsami z kochaną osobą i przesłani sobie swoje przeznaczenie.

Ulubioną literacką figurą Rilkego, którą posługuje się poeta, chcąc wskazywać płynność granic świata, który znamy i niedostępnego naszemu poznaniu kosmosu, są odrywające się od ziemi i swobodnie wzlatujące pod niebo ptaki.

Postaciami, które przerastają zwykłych śmiertelników potęgą uczucia, są dla Rilkego wielcy miłujący, a raczej wielkie miłujące, raczej kobiety niż mężczyźni, niedoznający odwzajemnionej miłości, kochający miłością czystą, bezinteresowną, której nie trzeba spełnienia. I święci, pozbawieni próżności, niczego nieżądający dla siebie, o których mówił Malte, że są gotowi ogrzać trędowatego ciepłem swego serca.

Inną jeszcze figurą, do której przywiązany jest Rilke, są przedwcześnie umarli. „Czego ode mnie żądają?” - pyta Ja- liryczne Elegii - „Muszę cicho zdjąć pozór / krzywdy, która ruch czysty ich duchów / od czasu do czasu nieznacznie obciąża” (Jastrun, s. 187). I dopowiada, by stało się jasne, co „pozór krzywdy” znaczy: „- Lecz żyjący wciąż popełniają / wszyscy ten błąd, że odróżniają zbyt mocno. Anioły - jak niesie wieść często nie wiedzą, czy idą / między żywymi czy umarłymi. Prąd wieczny / przez oba okręgi porywa pokolenia ludzkie, / unosząc wiecznie ze sobą, i zagłusza je w obu" (przekład Jastruna, s. 189).

Pierwesza i Druga Elegia są komplementarne względem siebie; dziwi mnie, że autorka omawianej tu książki do tej zależności nie przywiązuje wagi. Słusznie natomiast podkreśla osobliwości Trzeciej Elegii. Początek tego utworu narodził się na początku 1912 roku, w tym samym czasie, gdy poeta układał dwie pierwsze Elegie, a ukończona została późną jesienią roku 1913. Rilke zajmował się w tym czasie intensywnie nauką Freuda o seksualności człowieka, który m.in. wskazywał na istotną różnicę $\mathrm{w}$ podejściu do życia płciowego $\mathrm{w}$ starożytności i w czasach nowożytnych, polegającą na tym, że starożytni przypisywali największe znaczenie żądzy, my natomiast obiektowi naszego pożądania. Rilke był zafrapowany kultem popędu seksualnego w starożytności. Dał temu wyraz w Trzeciej Elegii, jak również w późniejszych Siedmiu Wierszach, zwanych fallicznymi, które ułożył w 1915 roku.

Trzecia Elegia zaczyna się od przeciwstawienia tradycyjnej poezji miłosnej, która wielbi ukochaną, i poezji ku czci, „owego ukrytego winnego rzecznego boga krwi" (nie winy - jak przekłada Jastrun i na którego przekład powołuje się w swoim omówieniu tego utworu autorka - tylko rzecznego boga, Neptuna). 
Kuczyńska-Koschany utrzymuje, że Trzecia Elegia jest jednoznaczna (ja nie odważyłabym się wypowiadać takiego sądu w odniesieniu do żadnej elegii Rilkego, bo wszystkie one są nieskończenie trudne do odczytania), a jednocześnie dostrzega trudności interpretacyjne. O tym mówi zaś coś dla mnie kompletnie niezrozumiałego: „Trudności interpretacyjne związane są z niepoetyckim wysłowieniem boga, zwanego Erosem; w polszczyźnie język erotyki albo jest poetycki, albo nie ma go wcale. Ten, którego nie ma wcale, brzmi wszędzie dokoła, jakby na złość obyczajowemu tabu" (s. 45). Czy autorka chce przez to powiedzieć, że język Rilkego w tej Elegii nie jest poetycki? Czy ma na myśli przekłady polskie, które poetyckie są? A może nie są? I co to za język, którego nie ma, a brzmi? Ale to uwagi na marginesie. Ważniejsza wydaje mi się konstatacja: „Już w pierwszej strofie pojawia się ta opozycja - nieobecnej Ukochanej i Neptuna krwi, boga »jątrzącego noc do wielkiego wrzenia «" (przekład Jastruna). Dlaczego autorka mówi o nieobecnej ukochanej? Jesteśmy wszak świadkami zbliżenia kochającej się pary.

Trzeba zajrzeć do oryginału i zwrócić uwagę na tryb przypuszczający we frazie „als wärest du nicht” (,jak nieobecna” thumaczy przecież Jastrun, a nie „nieobecna”). Cały problem polega na tym, że to nie kochanka podnieca chłopca, wzburzając jego krew, a Neptun, „władca rozkoszy”. Chłopiec traktuje ją, jakby jej nie było. Ona jest, niestety, jedynie obiektem zaspokojenia żądzy. Stąd bierze się skarga w tej Elegii, że zagłuszone zostało czyste uczucie kochanka, pochodzące ze sfer niebieskich: „[...] Gwiazdy, / czy nie od was pochodzi upodobanie kochanka / w twarzy umiłowanej? Czy jego wejrzenie w jej czyste oblicze / nie poczęło się z jasności konstelacji?"”. Bo przecież, czytamy w dalszej partii wiersza, że nie oddziałuje na chłopca jej łagodność w miłości, ani jego matki (wymowa tych wersów jest rzeczywiście dosyć jednoznaczna): „Nie ty napięłaś łuk jego brwi do takiego oczekiwania, / niestety, nie jego matka. Nie tobie, dziewczyno, / nie dla ciebie, która go kochałaś, [w oryginale nie ma czasu przeszłego, tam występuje „fühlendes Mädchen” - (czująca dziewczyno)] / nagięły się jego wargi do urodzajnej mowy. / Czy myślisz, że naprawdę twoje lekkie zjawienie / tak nim wstrząsnęło, lotna jak powiew poranny? / Choć zatrwożyłaś mu serce, to jednak starsze trwogi / uderzyły na niego przy najlżejszym dotyku" (przekład Jastruna, s. 197). Jastrun mówi o „najlżejszym dotyku”, podczas gdy Rilke o dotyku zdecydowanie mocniejszym „berührender Anstoß"; w wierszu Orpheus. Euridike. Hermes dotyk jest rzeczywiście najlżejszy, określony jako „unendlich leise [...] Berührung" - (chodzi o dotyk boga Hermesa). 
Dziewczynie przypada jednak w udziale uspokoić burzę zmysłów młodzieńca. Bo on tego pragnie, odpowiada na jej wołanie, odnajduje się w jej uczuciu, opanowuje się.

Interpretacją partii wiersza dotyczącej roli matki, która, podobnie jak teraz dziewczyna, potrafiła uładzić niepokoje erotyczne chłopca nawiedzające go $\mathrm{w}$ dzieciństwie, zastępując „smukłą postacią kłębiący się chaos”, Katarzyna KuczyńskaKoschany w zupełności mnie satysfakcjonuje. Potrafi się zachwycić, zwłaszcza drugą częścią drugiej strofy, którą przytacza w przekładzie Jastruna, mówiąc po prostu o tym fragmencie: „Jest piękny”.

Przekonujący jest jej długi wywód dotyczący problemów dojrzewania chłopca i przechodzenia w wiek męski.

$\mathrm{Na}$ koniec autorka wraca do swej konstatacji o klarownej konstrukcji utworu: „każdej strofie można by przyporządkować jeden temat, a następstwo tych tematów układa się w logiczną całość - została w mistrzowski sposób [...] powiązana z tematami nadrzędnymi. Z królewskim tematem poezji Rilkego - miłosną samotnością [...]; z wielkim tematem europejskiej kultury, z tematem krwi" (s. 55).

I w tym wypadku, jak w omówieniu Pierwszej Elegii, autorka zbywa nas ogólnym stwierdzeniem, bez odwoływania się do konkretów. Nie wymienia bowiem tematów poruszanych w każdej strofie, nie dowodzi, że ich układ jest logiczny i w sobie zamknięty. Zgadzam się ze stwierdzeniem, że wielkim tematem poezji Rilkego jest miłość samotnicza, ale trzeba by rozważyć, czy jest eksponowana właśnie w tej Elegii, a jeżeli tak, to w jakim sensie. Może w tym, że nawet w uścisku miłosnym złączenie nie jest zupełne. Nie jest to wszakże idea tożsama z tą, która głosi, że miłość prawdziwa, idealna wyklucza zbliżenie, a chyba w tym drugim sensie Kuczyńska-Koschany używa terminu miłości samotniczej, choć pewności nie mam. I upieram się, że temat krwi - poruszony na wstępie omawianej Elegii - wiąże się z kulturą antyczną przeciwstawioną nowoczesności. Wreszcie, że opozycja, którą poeta buduje w pierwszych dwóch wersetach, dotyczy - jak wspomniałam - tego, że czym innym jest opiewanie ukochanej w poezji hymnicznej, a czym innym Erosa, kryjącego się także pod imieniem Neptuna, ,rzecznego-boga”, „władcy rozkoszy”, którego siła oddziałuje - o czym mowa pod koniec utworu - już na embrion ludzki w wodach płodowych, jeszcze w łonie matki.

Rolą dziewczyny i matki jest dać ukojenie w gorączce. Lecz nie jest tak, by dziewczyna nie podlegała sile odwiecznej namiętności. Poeta mówi: „Spójrz, nie kochamy jak kwiaty, kwiaty jedynie z jednego / roku; kiedy kochamy, wlewa się w nasze żyły / 
sok z niepamiętnych czasów” (przekład Jastruna, s. 199). I w tym fragmencie utworu znajduję silny argument przeciwko zdecydowanemu przeciwstawianiu - na czym bazuje autorka - miłosnych zapędów kobiety i mężczyzny. Żałuję też, że nie przygląda się ona bliżej marzeniom sennym chłopca w powiązaniu $\mathrm{z}$ freudyzmem, bo jednak Elegia powstała w atmosferze dyskusji nad nauką Freuda o erotyzmie, prowadzonych przez Rilkego z Lou Andreas-Salomé po Kongresie Psychoanalitycznym w październiku 1913 roku.

Czwarta Elegia przynosi na wstępie piękne zawołanie „O Bäume des Lebens, o wann winterlich?” („O drzewa życia, kiedy zimujące?”; przekład Jastruna, s. 203), któremu autorka przygląda się uważnie, zestawiając różne przekłady tej frazy na polski, by dociec, która jest najbardziej zbliżona do oryginału. Zgadzam się z autorką, uznającą rozwiązanie Jastruna za najlepsze. Cieszę się, że w ocenie całej wstępnej strofy, która jest zwarta i zamknięta w sobie, Kuczyńska-Koschany powołuje się na Gadamera, którego tekst w thumaczeniu Małgorzaty Łukasiewicz udało mi się swego czasu zamieścić w „Literaturze na Świecie”. Przekonuje on, że inwokacja „O drzewa życia...” , „jest skierowana do nas. [...] Wspaniały układ pierwszego wersu opiera się właśnie na oczywistości odniesienia apostrofy: to o nas się tu mówi ze skargą. Nie jesteśmy podobni do wędrownych ptaków, które znają swój czas ani lwów, tak bardzo tożsamym ze swoim królewskim obejściem, że nie ma do nich dostępu słabość - słabością zaś chcieć tego, na co nie starcza możliwości” („Literatura na Świecie" 1979 , nr 10, s. 313 i n.)

Czwarta Elegia, powstała w 1915 roku, zdawała się zapowiadać powrót poety do pracy twórczej nad zaplanowanym cyklem, trudnym do realizacji w warunkach wojennych. Tematem wiodącym jest w niej kondycja ludzka, odmienna od sposobu bytowania zwierząt i ptaków, stworzeń żyjących w zgodzie z naturą, co daje im przewagę nad ulegającym słabościom rodzajem ludzkim. Nie miłość, a nienawiść jest nam najbliższa. Nawet w miłości nie doświadczamy pełnej zgodności uczuć, bo miłość to, jak mówi poeta, „Weite, Jagd und Heimat” („dal, łowy, ojczyzna”), co znaczy: otwieranie się na drugą osobę, pragnienie jej posiadania, zapewnienie sobie przy niej swojego bezpiecznego miejsca, ostoi.

Jednak obszary naszej szczęśliwości, raj, który jest naszym udziałem, nie jest nam dany na zawsze. Jednym z podstawowych życiowych doświadczeń bywa rozstanie. Inscenizację rozstania prezentuje środkowa cześć drugiej strofy wiersza. Rozgrywa się ona w samym centrum uczuć: na scenie serca. Głównym wyko- 
nawcą roli na tej chybotliwej - jak się okazuje - scenie jest tancerz, ale nie ten, który powinien był w niej wystąpić. Ten, który występuje w teatrze, okazuje się być mieszczaninem w zwodniczej masce artysty. Poeta wyrzuca zatem przebierańca ze sceny, zastępując go lalką. Lalce poświęcił Rilke jeden ze swoich esejów: Lalki (O lalkach woskowych Lotty Pritzel) z 1914 roku, o którym autorka wspomina. Jednakże uwzględnia ona tylko tę charakterystykę lalki, która odnosi się do dziecięcej zabawki - dla Rilkego obrzydliwej, podczas gdy woskowe lalki Lotty Pritzel nie są lalkami dla dzieci, lecz wdzięcznymi figurynkami w rokokowym stylu, obdarzonymi lekkością ruchu. Rilke pisze najwyraźniej o lalce na drucie, a to marionetka. Wiadomo, że żywo interesował się teatrem marionetek i niejednokrotnie wypowiadał na ten temat.

Przy objaśnianiu strofy, w której pojawiają się współgrające ze sobą figury lalki i anioła, autorka chowa się za tekst Gadamera. Szkoda, że nie próbuje wskazać na możliwości interpretacyjne tej części utworu, jakie daje uwzględnienie lektur Rilkego, a zwłaszcza eseju Kleista o teatrze marionetek, którym Rilke się zajmował. Marionetkę i anioła łączy w szczególności lekkość, gracja, z jaką mogą się poruszać.

Włączając się do sporu rilkologów o to, czy można utożsamiać lalkę z eseju Puppen z lalką z Czwartej Elegii, twierdzę że tak - że można. Tylko nie lalkę bez duszy, z ciałem przeraźliwie obcym, „dla którego zmarnowaliśmy nasze najczystsze zapały; jako nieudolnie pomalowany topielec, który pozwalał się unosić i podtrzymywać powodziom naszych czułości do momentu, w którym na powrót wysychaliśmy i zostawialiśmy go gdzieś w zaroślach" (przekład Ososińskiego, s. 152), lecz tę, o której jest mowa pod koniec eseju: „nowy rodzaj delikatnych motyli trzepocących skrzydłami, unoszący się wśród nas i budzący niejasne przeczucia” (przekład Ososińskiego, s. 157).

Lalkę-zabawkę dla dzieci przeciwstawił Rilke w swym eseju marionetce, pisząc: „Poeta mógłby dostać się pod władzę marionetki, bo marionetka obdarzona jest fantazją. Lalka jest jej pozbawiona i stoi dokładnie o tyle niżej niż rzecz, o ile marionetka nad rzeczą góruje" (przekład Ososińskiego, s. 154).

Rilke zatem imaginuje w Elegii lalkę-marionetkę, która podrywa się i daje popis, poruszana rękami anioła - przymuszonego do występu przez wpatrzonego $\mathrm{w}$ opustoszałą scenę i idealnie odgrywającego przed jego wzrokiem swą wiodącą rolę. Nie ulega dla mnie wątpliwości, że Rilke ma na myśli potencję artystyczną. To oczy artysty patrzą tak wytrwale, aż wypatrzą widowisko natężenia jego wzroku godne. 
Utwór nabiera charakteru osobistych wyznań, choć można je uogólnić. Potrzeba akceptacji ojca dla pracy artystycznej, której się Rilke oddawał, wyrażona w tej partii Elegii, jest autentyczna. Także po śmierci ojca, bo przecież kontakt ze zmarłym pozostał. Również wszyscy inni, z którymi poeta, a raczej ja poetyckie wiersza było związane uczuciowo, zbyt go kochali, przejawiając troskę o jego byt materialny i krępując nadmiarem swojej miłości jego wzloty w przestrzenie dalsze niż świat wytłumaczalny. Mamy tu zatem refleksje Rilkego, z jakimi spotkaliśmy się już przy lekturze Pamiętników Maltego Lauridsa Brigge. Ma ona osobliwe zakończenie, jakie stanowi nowa wersja legendy o synu marnotrawnym. Ten, którego obmyślił poeta, nie chce być kochany. Pragnie pozostać sobą, odrzuca zależność od ojca rodziny, która chce go ograniczać nadmierną miłością.

Elegia, wyrażając i rozwijając myśl o drzewach życia, reflektuje nad sensem istnienia, nad istotą ludzką z jej potencjami, możliwościami rozwoju i ograniczeniami. Dziecko ucieleśnia wzorzec człowieka doświadczającego jedności w sobie i zgody $\mathrm{z}$ naturą, od samego poczęcia po moment odejścia. Jedność ta jest nie do utrzymania w życiu dorosłego. To egzystencja wypełniona sprzecznościami, rozdarciem wewnętrznym, niepewnością i lękiem.

Ostatnie partie wiersza koncentrują się na sensie naszych dokonań. Żyjąc, nie sięgamy sedna rzeczy. Do tego trzeba doświadczeń granicznych. One są dane umierającym. Przedwczesna śmierć, śmierć dziecka - o której słyszymy na końcu - wydaje się być niesłychaną okropnością, bo nie potrafimy się z nią pogodzić. Inaczej niż dziecko, jednakowo otwarte na życie i na śmierć.

W interpretacji tego utworu zaproponowanej przez Katarzynę Kuczyńską-Koschany natrafiam na wypowiedzi, które dla mnie są niejasne. Tak się dzieje na przykład w akapicie „Świadkowie sensu", do których - dla Kuczyńskiej-Koschany - należą umarli. $\mathrm{O}$ ile rozumiem i podzielam opinię Gadamera, który tłumaczy: „O ojcu dawno zmarłym mówi się, że cechuje go obojętność zmarłych i że wyrzeka się tej obojętności dla nas" (na marginesie dodam, że tak właśnie - akcentując obojętność, bez wyrzekania się jej oczywiście - opisałam swego czasu w swojej interpretacji stan Eurydyki w wierszu Orfeusz, Eurydyka, Hermes z cyklu Nowych Wierszy), to nie wiem, jak rozumieć komentarz autorki do fragmentu wiersza, gdzie mowa o umarlym ojcu:

To ów ojciec uwewnętrzniony, więc $\mathrm{w}$ jakimś stopniu sfunkcjonalizowany, zobojętniony ( $\mathrm{w}$ takim sensie, $\mathrm{w}$ jakim używa się tego 
określenia w chemii), staje się miarą naszego losu, naszego wyboru, nigdy niewolnego od udziału innych - tak czy inaczej poprzedzających nas w istnieniu (ojciec, anioł):

ty, który, mój ojcze, odkąd umarłeś, często w nadziei mojej, wewnątrz mnie lękasz się, i obojętność, tę zmarłych własność, tron, z obojętności oddajesz za krztę mego losu.

(Przekład A. Chlewińskiego)

Umarły jest skazany na obojętność czy raczej na to, czym przybliżając znane, thumaczymy nieznane: skazany na los za sobą; innymi słowy, umarły pokazuje wartość losu usytuowanego przed sobą, tego, przed którym żyjący może odczuwać naturalny lęk (s. 68).

Nie chcąc się wdawać w dłuższą polemikę, przyznam, że nie rozumiem, co ma znaczyć zestawienie ojca z aniołem. Poprzedzają nas w istnieniu, zgoda. Ale przecież nie to jest przedmiotem dyskusji. Przedmiotem dyskusji są zagrożenia niezależnego, własnego bytu człowieka (w Maltem Rilke operuje kategoriami własnego życia i własnej śmierci). Ojciec był w życiu poety tym, który go ograniczał swoim zatroskaniem, i taki powraca w jego poezji, bo jego lęki trwają „wewnątrz mnie” (słowem, ojciec mieści się w pojęciu „świat”; anioł natomiast jest figurą, która uwzniośla, podnosi, porywa człowieka ze świata („Welt”) w przestrzeń otwartą („Weltraum”).

Każda elegia w złożonym przez Rilkego cyklu stanowi w sobie pewną zamkniętą całość, dlatego najsensowniej jest - według mnie - omawiać te utwory osobno. Wychodząc z tego założenia, omówiłam tutaj kilka z nich, mianowicie te, które powstały najwcześniej, w latach 1912-1915. Tak dokładna, krytyczna lektura wszystkich dziesięciu elegii jak ta, której poddałam cztery pierwsze, byłaby zapewne dla czytelnika nużąca. Sądzę, że to, co miałam do powiedzenia o książce Katarzyny Kuczyńskiej- Koschany, wyraziłam jasno. Należy cieszyć się z ukazania tej książki, bo jest to pierwsza próba syntetycznego opracowania Elegii duinejskich, ze zwróceniem uwagi na istniejące polskie przekłady, na ich walory i mankamenty, i ze zwróceniem uwagi na interpretacje Elegii, które wyszły spod piór znanych niemieckich krytyków literatury i filozofów. Autorka postawiła sobie ambitne zadanie do wykonania, i to jest godne pochwały. Mimo wszystko jej praca nie może w pełni zadowalać. Mam wrażenie, że nie zajrzała do wydania krytycznego dzieł Rilkego, opracowanego przez Manfreda Engela, Ulricha Fülleborna, Horsta Nalewskiego i Augusta Stahla, bez którego żaden rilkolog już się dziś obyć nie 
może. Wydaje mi się także, że nazbyt często zawierza bardziej któremuś z polskich thumaczy Rilkego niż jemu samemu. Czasami w jej odczytaniach oryginalnych wersji utworów, jak też tekstów interpretatorów tych utworów pojawiają się irytujące błędy i przeinaczenia. Zostaje więc poczucie niedosytu i oczekiwanie na dalsze, ambitne książki o Rilkem po polsku i kolejne, wciąż możliwe tłumaczenia jego niezwykle trudnej, osobliwej, a wielce urokliwej prozy i poezji, w której jest jeszcze dużo do odkrycia.

\section{BARBARA L. SUROWSKA}

\section{On reading the "Duino Elegies" by Rainer Maria Rilke}

The article discusses the book Rycerz $i$ śmierć written by Katarzyna Kuczyńska-Koschany. The book includes essays on Reiner Maria Rilke's Duino Elegies published earlier that have been revised and updated. The poem cycle called the Duino Elegies is composed of ten separate poems written in 1912, 1913, 1915 and 1922, i.e. at the peak period of the poet's imagination and mental activity. The reviewer provides a detailed analysis of the first four chapters of the book in which three elegies written before the outbreak of the first war, and the fourth that originated when the war was raging on, are presented. The reviewer appreciates the author's careful preparation for the book and the ambitious agenda of the author to describe in a synthetic form, for the first time in Poland, the whole cycle of Rilke's elegies with their Polish translations along with their quality evaluation and comparison taken into consideration, as well as some presentations of German interpretations from prominent specialists in the life and the literary output of Rilke. However, the reviewer is not ready to buy all of the author's claims and points at numerous, perhaps too numerous, errors, distortions in facts and erroneous reading of the original texts written in German, which, to a high degree, lowers the perceived quality of the discussed book.

Key words: figure of a doll and an angel, Dingedicht, Malte, Sonnets, Elegies, Weltinnenraum, bird flight, prematurely dead, saints, reclusive love, Eros, death.

Barbara L. Surowska - prof. germanistyki, literaturoznawca na Uniwersytecie Warszawskim, zajmuje się przede wszystkim literaturą niemiecką XVIII-XX wieku; najważniejsze publikacje: Die Bewußtseinsstromtechnik im Erzäblwerk Arthur Schnitzlers (Technika strumienia świadomości w twórczości prozatorskiej Artbura Schnitzlera) (1990); Metamorfozy stylu w twórczości Rainera Marii Rilkego (od lat najwcześniejszych po okres paryski) (1992); Mtody Rilke (1994); Von überspannten Ideen zum politischen Appell. 25 Essays zur deutschen Literatur (Od zwariowanych pomystów do politycznego apelu. 25 esejów o literaturze niemieckiej) (2006); Związi Rainera Marii 
Rilkego z dziedzina sztuk pięknych (2008); prace edytorskie: Panna Elza i inne opowiadania, wybór utworów nowelistycznych A. Schnitzlera, przeł. M. Wisłowska i J. Frühling (1971); In der Nacht wandern die Bäume (W nocy drzewa chodza), antologia opowiadań polskich, wybór i wstęp B. Surowska i K. Sauerland (1982); Franz Kafka, Osiem notatników (Oktavbefte), edycja, przekład i posłowie B. Surowska (1995); Das intellektuelle Europa der Jabrbundertwenden (Intelektualna Europa na przetomie wieków), edycja i wstęp B. Surowska (2000); Zygmunt Łempicki, intelektualista okresu międzywojennego, wprowadzenie B. Surowska (2002); Dir zur Feier..., ed. G. Kwiecińska, B. Chołuj, B. Surowska i A. Wołkowicz (2007).

e-mail: b.surowska@uw.edu.pl 